Вісник Харківського національного університету імені В.Н. Каразіна Серія "Математика, прикладна математика і механіка"

Том 89,2019 , с. $93-101$

УДК 517.977
Visnyk of V.N.Karazin Kharkiv National University Ser. "Mathematics, Applied Mathematics and Mechanics"

Vol. 89, 2019, p. 93-101

DOI: $10.26565 / 2221-5646-2019-89-07$

\title{
Controllability of the linear switched dynamical systems of the special type
}

\author{
V.I. Korobov, A.I. Derevianko \\ V. N. Karazin Kharkiv National University, Kharkiv, 4 Svobody sqr., 61022, \\ Ukraine \\ korobov@karazin.ua,derev.anna.08.96@gmail.com
}

In this paper, the controllability of a special type of linear switched systems is studied. Switch is carried out between two $2 \times 2$ matrices with purely imaginary eigenvalues. Such a system describes oscillations of a spring pendulum with a switchable stiffness coefficient. The main result of the work is an algorithm that allows finding a set of switching signals for switching from point to point, and a theorem for switching systems with a block-diagonal matrix.

Keywords: linear switched systems; controllability; switching way; getting to the given point; spring pendulum.

Коробов В.I., Дерев'янко А.І. Керованість лінійними динамічними системами перемикання спеціального типу. У даній роботі вивчається керованість лінійних систем перемикання спеціального типу. Перемикання відбувається між двома $2 \times 2$ матрицями з чисто уявними власними значеннями. Така система описує коливання пружинного маятника 3 коефіцієнтом жорсткості, який перемикається. Основним результатом роботи $\epsilon$ алгоритм, що дозволяє визначити набір сигналів перемикання для переходу з точки в точку, і теорема про керованість для систем перемикання 3 блочно-діагональною матрицею.

Ключові слова: лінійні системи перемикання; керованість; спосіб перемикання; потрапляння в задану точку; пружинний маятник.

Коробов В.И., Деревянко А.И. Управляемость линейными динамическими системами переключения специального типа. В данной работе изучается управляемость линейных систем переключения специального типа. Переключение происходит между двумя $2 \times 2$ матрицами с чисто мнимыми собственными значениями. Такая система описывает колебания пружинного маятника с переключающимся коэффициентом жесткости. Основным результатом работы является алгоритм, позволяющий найти набор сигналов переключения для перехода из точки в точку, и теорема об управляемости для систем переключения с блочно-диагональной матрицей.

Ключевые слова: линейные системы переключения; управляемость; способ переключения; попадание в заданную точку; пружинный маятник.

2010 Mathematics Subject Classifications: 93C15; 93B05.

(c) V.I.Korobov, A. I. Derevianko, 2019 


\section{Introduction and Statement of the Problem}

Switched systems is a special case of hybrid dynamical systems with discrete and continuous dynamics. They are widely applied when a real system cannot be described by one single model. Numerous examples are given by engineering systems of electronics, power systems, traffic control and others. Since the 1990s, the issue of switched systems stability has become very popular (see [1], [3]). The particular case of linear switched systems was considered in [2]. More modern literature about switched systems is presented by works of Patrizio Colaneri [2], Yuan Lin, Yuan Sun-Ge Wang, and Jiang-Wang [4], Zhong-Ping, Yuan Wang [5]; the question of stability remains popular nowadays.

In the present paper we consider one particular class of switched system from the point of view of controllability property.

Let us recall the basic terminology. By a switched system we mean the following system

$$
\dot{x}(t)=f_{\sigma(t)}(x(t)), \quad x(0)=x_{0}
$$

where $x \in \mathbb{R}^{m}$ is called a continuous state, $\sigma$ stands for a discrete state with values from an index set $M:=\{1, \ldots, n\}$, and $f_{k}$, for $k \in M$, are given vector fields.

The behavior of the dynamical system is regulated by the switching signal. Namely, at some moments $\tau_{1} \ldots \tau_{n}$ the signal changes its value from $\sigma\left(\tau_{i}\right)$ to $\sigma\left(\tau_{i+1}\right)$, hence the trajectory of the system, starting from $t=\tau_{i}$, is given by the vector field $f_{\sigma\left(\tau_{i+1}\right)}$ instead of $f_{\sigma\left(\tau_{i}\right)}$. In works on switched systems, switching times can be random or given by some law. It is clear that stability depends both on vector fields and on the switching law.

In our work, we consider a slightly different formulation of the problem, namely, the switching signal is under our control.

We introduce the following definition.

Definition 1 We say that the switched system

$$
\dot{x}(t)=f_{\sigma(t)}(x(t)), \quad x(0)=x_{0}
$$

is controllable if for any two points there exists a switching signal that allows to get from the first point to the second one.

This definition corresponds to the concept of controllability for control systems of the form

$$
\dot{x}=f(x, u), \quad x(0)=x_{0},
$$

where the control $u(t)$ plays the role of a switching signal.

In this paper we consider linear switched systems (see [2]) of the form

$$
\dot{x}(t)=A_{\sigma(t)} x(t), \quad x(0)=x_{0} \neq 0,
$$

where $A_{1} \ldots A_{n}$ are given matrices. Our main goal is studying the case $m=2$, $n=2$ with both systems having pure imaginary eigenvalues, which are introduced 
in Section 1. We show that such systems are controllable and propose an algorithm for constructing a controlling switching signal; the algorithm is presented in Section 2. Section 3 contains one generalization.

\section{Controllability of $2 \times 2$ linear switched dynamical systems}

Consider the problem of oscillation of a spring pendulum

$$
\ddot{x}=-k x
$$

with a switchable stiffness coefficient $k>0$. Assume that we have a spring with a stiffness coefficient $k_{1}$, and we can change the stiffness coefficient of the system by joining and removing an additional spring with a stiffness coefficient $k_{2}$.

Two cases can be considered. If the springs are connected in parallel, the parameter $k$ of the system switches between $k=k_{1}$ and $k=k_{1}+k_{2}$. If the connection is series, the parameter $k$ of the system switches between $k=k_{1}$ and $k=\frac{k_{1} k_{2}}{k_{1}+k_{2}}$.

Let us rewrite the differential equation of the pendulum occilations as a switched system:

$$
\dot{x}(t)=A_{i} x(t)
$$

where

$$
A_{1}=\left[\begin{array}{rr}
0 & 1 \\
-\alpha & 0
\end{array}\right], \quad A_{2}=\left[\begin{array}{rr}
0 & 1 \\
-\beta & 0
\end{array}\right] .
$$

For definiteness, let us assume that we start and end with the first system. Suppose that two nonzero points (initial $\left(x_{1}, y_{1}\right)$ and ending $\left.\left(x_{2}, y_{2}\right)\right)$ are given.

So we have two cases: $\beta>\alpha$ and $\beta<\alpha$. Notice that under the parallel connection condition we can get only $\beta>\alpha$.

\subsection{Case $\alpha>\beta$.}

Rewrite coordinates of $x$ as $(x, y)$. Solutions of the system

$$
\dot{x}(t)=A_{1}(x(t))
$$

are of the form

$$
\begin{aligned}
& x(t)=\gamma_{1} \sin (\sqrt{\alpha} t)+\gamma_{2} \cos (\sqrt{\alpha} t), \\
& y(t)=\sqrt{\alpha} \gamma_{1} \sin (\sqrt{\alpha} t)-\sqrt{\alpha} \gamma_{2} \cos (\sqrt{\alpha} t),
\end{aligned}
$$

while solutions of the system

$$
\dot{x}(t)=A_{2}(x(t)) .
$$

are of the form

$$
\begin{aligned}
& x(t)=\delta_{1} \sin (\sqrt{\beta} t)+\delta_{2} \cos (\sqrt{\beta} t), \\
& y(t)=\sqrt{\beta} \delta_{1} \sin (\sqrt{\beta} t)-\sqrt{\beta} \delta_{2} \cos (\sqrt{\beta} t) .
\end{aligned}
$$


So the trajectories are given by ellipses of the following types:

$$
x^{2}+\frac{y^{2}}{\alpha}=c^{2}
$$

(we call them horizontal ellipses) and

$$
x^{2}+\frac{y^{2}}{\beta}=c^{2}
$$

(we call them vertical ellipses). Phase portraits are presented in Fig. 1.
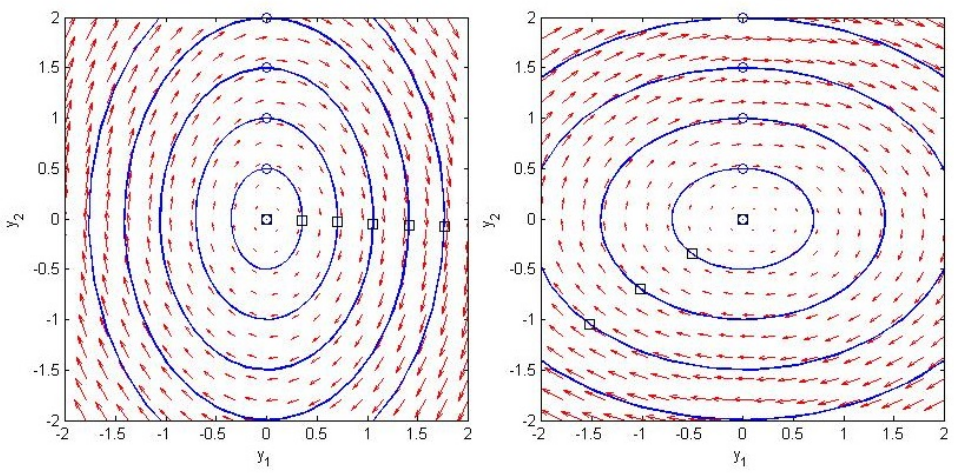

Fig. 1. Phase portraits for the first (left) and the second (right) systems with $\alpha=2, \beta=\frac{1}{2}$

Let the trajectory (1) go through the initial point $\left(x_{1}, y_{1}\right)$ and the trajectory (2) go through the end point $\left(x_{2}, y_{2}\right)$. Denote

$$
c_{1}=\min \left(\gamma_{1}^{2}+\gamma_{2}^{2} ; \delta_{1}^{2}+\delta_{2}^{2}\right)
$$

and

$$
c_{2}=\max \left(\gamma_{1}^{2}+\gamma_{2}^{2} ; \delta_{1}^{2}+\delta_{2}^{2}\right) .
$$

Let us fix the vertical ellipses $x^{2}+\frac{y^{2}}{\beta}=c_{1}^{2}, x^{2}+\frac{y^{2}}{\beta}=c_{2}^{2}$ and find the conditions under which they have a common horizontal ellipse $x^{2}+\frac{y^{2}}{\alpha}=d^{2}$, i.e., intersecting both.

Consider the smaller vertical ellipse $x^{2}+\frac{y^{2}}{\beta}=c_{1}^{2}$. The horizontal ellipse circumscribing it looks like $x^{2}+\frac{y^{2}}{\alpha}=\frac{\alpha}{\beta} c_{1}^{2}$. Now we consider the bigger vertical ellipse $x^{2}+\frac{y^{2}}{\beta}=c_{2}^{2}$. The horizontal ellipse inscribed in it is $x^{2}+\frac{y^{2}}{\alpha}=c_{2}^{2}$. So we get that intermediate horizontal ellipses (see Fig. 2) exist under the condition $c_{2}<\sqrt{\frac{\alpha}{\beta}} c_{1}$. They have the form $x^{2}+\frac{y^{2}}{\alpha}=d^{2}$, where $d \in\left(c_{2} ; \sqrt{\frac{\alpha}{\beta}} c_{1}\right)$.

If this is not the case, that is, two ellipses of the first family do not have a common ellipse of the second family, then we build the intermediate vertical 


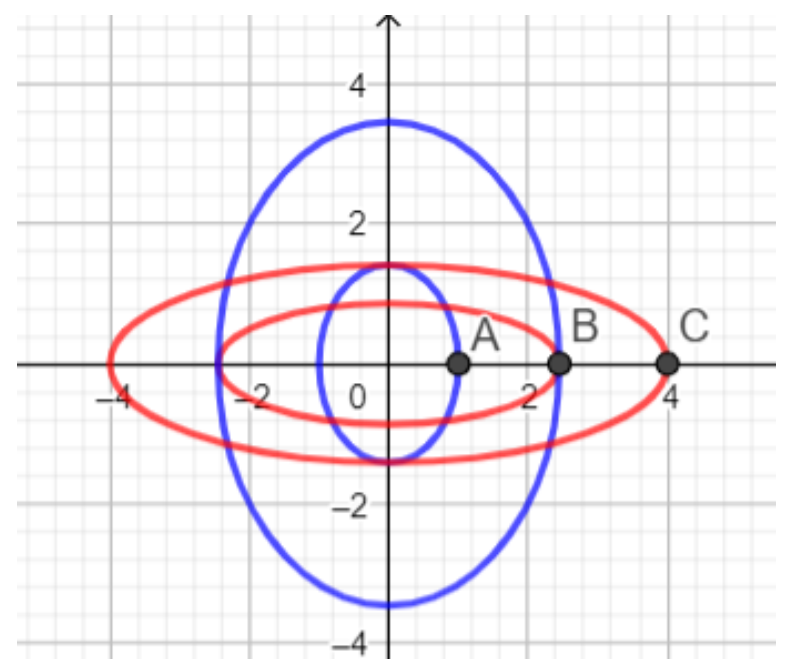

Fig. 2. $A\left(c_{1}, 0\right), B\left(\sqrt{\alpha / \beta} c_{1}, 0\right), C\left(\alpha / \beta c_{1}, 0\right)$

ellipse $x^{2}+\frac{y^{2}}{\beta}=\frac{\alpha}{\beta} c_{1}^{2}$, and repeat the described procedure. Now the condition of existence of a common horizontal ellipse takes the form $c_{2}<\frac{\alpha}{\beta} c_{1}$.

After $N=\left[2 \log _{\alpha / \beta} c_{2} / c_{1}\right]$ such steps we get the set of vertical and horizontal ellipses. Thus, it is possible to organize getting from the initial point to the end point. Therefore we have shown that the switched system is controllable.

\subsection{Case $\alpha<\beta$.}

Now it is natural to refer to (3) as vertical ellipses and (4) as horizontal ellipses.

Unlike the previous case, the initial and end ellipses are horizontal (see Fig. 3). Then the number of intermediate ellipses is also estimated as $N=\left[2 \log _{\alpha / \beta} c_{2} / c_{1}\right]$ and the system is controllable.

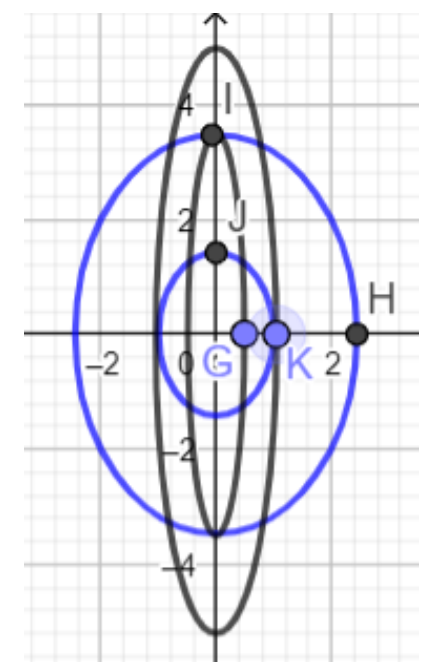

Fig. 3. $G\left(c_{1}, 0\right), K\left(c_{2}, 0\right), I\left(0, \sqrt{\alpha} c_{1}\right), H\left(\sqrt{\frac{\alpha}{\beta}} c_{1}\right), J\left(0, \frac{\alpha}{\beta} c_{2}\right)$ 


\section{Algorithm of finding the controlling switching signals}

The obtained results allow us to propose an algorithm of getting from an initial point to an end point for the system under consideration.

1. Get initial and final points $\left(x_{1}, y_{1}\right),\left(x_{2}, y_{2}\right)$.

2. Calculate

$$
c_{1,2}=\sqrt{x_{1,2}^{2}+\frac{y_{1,2}^{2}}{\alpha}} .
$$

Build initial and final ellipses $x_{1,2}^{2}+\frac{y_{1,2}^{2}}{\alpha}=c_{1,2}^{2}$.

3. Define intervals $\left[c_{1}, \sqrt{\frac{\alpha}{\beta}} c_{1}\right],\left[c_{2}, \sqrt{\frac{\alpha}{\beta}} c_{2}\right]$.

4. If there exists $d \in\left[c_{1}, \frac{\alpha}{\beta} c_{1}\right] \cap\left[c_{2}, \frac{\alpha}{\beta} c_{2}\right]$ then build ellipse $x^{2}+\frac{y^{2}}{\beta}=d^{2}$.

Otherwise define $c_{1}:=\sqrt{\frac{\alpha}{\beta}} c_{1}$, build ellipses $x_{1,2}^{2}+\frac{y_{1,2}^{2}}{\alpha}=c_{1}^{2}, x^{2}+\frac{y^{2}}{\beta}=\frac{\alpha}{\beta} d^{2}$, return to item 3 .

5. Build $N$ auxiliary ellipses till the intersection with $x^{2}+\frac{y^{2}}{\alpha}=c_{2}^{2}$. Find intersection points, get the way from point to point by choosing the closest point in needed direction.

Consider the following example, which generalizes the system from [6, p. 6]. Suppose the matrices to be of the form

$$
A_{1}=\left[\begin{array}{rr}
0 & 1 \\
-\alpha & 0
\end{array}\right], \quad A_{2}=\left[\begin{array}{rr}
0 & 1 \\
-1 / \alpha & 0
\end{array}\right]
$$

$\alpha=4$, the initial point is $(-50,-11)$, and we need to find the way to the point $(6,1)$. Using the MATLAB program we get a collection of ellipses and a switching path.

In our case the set of switching points is:

$\{(45.4832,44.3520),(0.0000,48.3322),(24.1661,0.0000),(0.0000,12.0830)\}$

and one possible trajectory is drawn in Fig. 4.

\section{Generalization}

Let us suggest a generalization to linear switched systems of higher dimension.

Theorem 1 Let us consider a switched system of the form

$$
\dot{x}(t)=A_{i}(x(t)), \quad x(0)=x_{0} \neq 0,
$$




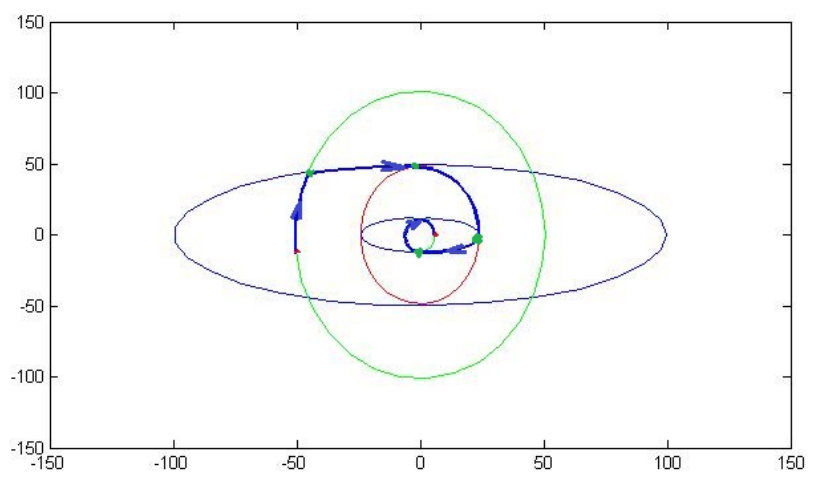

Fig. 4. Possible trajectory

where $A_{i}$ are block-diagonal matrices of dimension $2 n \times 2 n$

$$
A_{i}=\left(\begin{array}{cccc}
A_{i_{1}}^{1} & & & 0 \\
& A_{i}^{2} & & \\
& & \ddots & \\
0 & & & A_{i}^{n}
\end{array}\right), \quad i_{j}=1,2, \quad i=\left(i_{1} \ldots i_{n}\right),
$$

where $A_{i}^{j}$ are given $2 \times 2$ matrices. The switched system

$$
\dot{x}(t)=A_{i}(x(t)), \quad x(0)=x_{0} \neq 0
$$

is controllable if and only if the systems

$$
\dot{x}(t)=A_{i}^{j}(x(t)), \quad x(0)=x_{0} \neq 0, \quad i=1,2, \quad j=1 \ldots n
$$

are controllable.

\section{Conclusion on the results and directions for further research}

In this work, the controllability of switched linear systems of the special type was studied.

Namely, linear switched system with purely imaginary eigenvalues of both matrices are considered.

The main result of the work is an algorithm, that allows to find a set of switching signals for getting from point to point.

We also formulated the theorem that states the controllability of the switched system of one special type with a block-diagonal matrix.

In the future, we plan to study the behavior and controllability of switched systems with different types of eigenvalues (real and complex) and switched systems of higher dimension.

$$
\text { ORCID ID }
$$

V.I. Korobov (iD https://orcid.org/0000-0001-8421-1718

A.I. Derevianko (iD https://orcid.org/0000-0003-1105-8745 


\section{REFERENCES}

1. M. Vidyasagar. Nonlinear System Analysis, 2nd ed. New Jersey: Prentice Hall, Eaglewood Cliffs, 1993.

2. P. Colaneri. Analysis and Control of Linear Switched Systems. Politecnico di Milano, 2018, http://users.dimi.uniud.it/ franco.blanchini/scuolasidra09/SW.pdf

3. Z. Sun, S. S. Ge. Stability Theory of Switched Dynamical Systems. New York: Springer-Verlag London, 2011.

4. Y. Lin, E. D. Sontag, Y. Wang. A Smooth Converse Lyapunov Theorem for Robust Stability, SIAM Journal on Control and Optimization. - 1996. - Vol. 34, No. 1. - P. 124-160.

5. Z.-P. Jiang, Y. Wang. A converse Lyapunov theorem for discrete-time systems with disturbances, Systems and Control Letters. - 2002. - Vol. 45, No. 1. - P. 49-58.

6. W.A. Coppel. Stability and Asymptotic Behavior of Differential Equations. Boston: D. C. Heath and Company, 1965.

7. J. Polking. Ordinary Differential Equations Using MATLAB, 3rd ed. Pearson, 2004.

8. L.S. Pontryagin. Ordinary Differential Equations. Moscow, 1974.

9. A.I. Derevianko, V.I. Korobov. Controllability of the given switched linear system of special type, Technical Sciences: problem and solutions. Moscow, 2019 .

V.I. Korobov, A.I. Derevianko. Controllability of the linear switched dynamical systems of the special type. Switched systems is a special case of hybrid dynamical systems with discrete and continuous dynamics. They are widely applied when a real system cannot be described by one single model. In theoretical works on switched systems, switching signals and times can be random or given by some law. Stability depends both on vector fields and on the switching law. In the present paper, a different formulation of the problem is considered, that is the case, when switching signal is under our control. Namely, a switched system is called controllable if for any two points there exists a switching signal that allows to get from the first point to the second one. In the paper the controllability of linear switched systems of a special type is studied. More specifically, we consider a switch, that is carried out between two $2 \times 2$ matrices with purely imaginary eigenvalues of both matrices. In the first section we discuss the physical meaning of switched systems of this type. Namely, the problem of oscillation of a spring pendulum with a switchable stiffness coefficient is considered with the series and parallel connection of an additional spring to the system with one given spring. We prove that such a system 
is controllable, and propose the method of finding the controlling switching signal. In the second section we present the main result of the work. We formulate an algorithm that allows finding a set of switching signals for getting from any given initial point to any given end point. We present an example of such controlling switching signals, simulated in MATLAB. In the last section we propose a generalization of the obtained result and formulate the theorem that states the controllability of the special type switched system with a block-diagonal matrix of high dimension. The method presented in the paper can be generalized to study of controllability of linear switched systems of more general form.

Keywords: linear switched systems, controllability, switching way, getting to the given point, spring pendulum.

Коробов В.I., Дерев'янко А.І. Керованість лінійними динамічними системами перемикання спеціального типу. Системи перемикання - це окремий випадок гібридних динамічних систем з дискретною і неперервною динамікою. Вони широко застосовуються, коли реальна система не може бути описана однією єдиною моделлю. У теоретичних роботах по системам перемикання сигнали і час перемикання можуть бути випадковими або контролюватись яким-небудь законом. Стійкість залежить як від векторних полів, так і від закону перемикання. У даній роботі розглядається інша постановка задачі, тобто випадок, коли сигнал перемикання знаходиться під нашим контролем. А саме, система перемикання називається керованою, якщо для будь-яких двох точок існує сигнал перемикання, що дозволяє потрапити з першої точки до другої. У статті вивчається керованість лінійних систем перемикання спеціального типу. Точніше, ми розглянемо перемикання, яке виконується між двома матрицями $2 \times 2$ з чисто уявними власними значеннями обох матриць. У першому розділі ми обговорюємо фізичний зміст систем перемикання цього типу. А саме, задача коливання пружинного маятника з коефіцієнтом жорсткості, що перемикається, розглядається при послідовному і паралельному приєднанні додаткової пружини до системи з однією даною пружиною. Доводиться, що така система є керованою, і пропонується спосіб пошуку сигналів перемикання. У другому розділі ми представляємо основний результат роботи. Формулюється алгоритм, який дозволяє знайти набір сигналів перемикання для потрапляння з будь-якої початкової точки в будь-яку задану кінцеву точку. Наведено приклад такого керування перемикальними сигналами, змодельований в MATLAB. B останньому розділі ми пропонуємо узагальнення отриманого результату та формулюємо теорему, в якій стверджується керованість системи перемикання спеціального типу з блочно-діагональною матрицею вищої розмірності. Метод, представлений у статті, можна узагальнити для вивчення керованості лінійних систем перемикання більш загального вигляду.

Ключові слова: лінійні системи перемикання; керованість; спосіб перемикання; потрапляння в задану точку; пружинний маятник.

Article history: Received: 14 May 2019; Final form: 20 May 2019;

Accepted: 21 May 2019. 